\title{
BTG has big plans for US
}

\section{London}

For the British Technology Group (BTG), it has been a year of living dangerously. Where just 12 months ago it rested in the safe embrace of UK government ownership and steadily climbing profits, BTG is now in the midst of a leap towards independence and an ambitious move into the United States. It has opened a new company - BTG-USA to mine what its officials privately describe as a "vast, untapped market" of neglected US inventions, and at the same time it is orchestrating a massive political campaign to become a private company.

Last week, it released its first annual financial results since the opening of BTG-USA, and although the strain of growth is showing (setting up the US arm cut $£ 3$ million in profits off last years's figure of $£ 9.5$ million), it appears that the gamble may actually pay off. Nearly 80 per cent of BTG's $£ 31$ million income now comes from abroad, of which about half is from the United States. BTG-USA is about to announce its first agreement with a US university for a blanket technology transfer deal - a long-term profitsharing arrangement with Princeton University to find buyers for the university's research. A recent survey by the technology transfer office of the Massachusetts Institute of Technology found that BTG has generated more patents and licences than all US university technology transfer offices combined. And in the midst of a recession, overall BTG revenue was still up by about 3 per cent.

This is heady stuff for a company that was set up in the 1940 s by the government essentially as a marketing tool for UK universities. Since its modest creation, BTG has become the undisputed world leader in technology transfer - not, perhaps, as remarkable as it sounds, given that there is little competition.

With the exception of the smaller Arizona-based Research Corporation Technologies (RCT), no other major international technology transfer companies exist. "They're really our only competition in the world," says Gary Munsinger, RCT president. "I can see why they'd want to come to the United States."

If company estimates are right, BTGUSA can choose from a $£ 10,000$ million crop of undeveloped - but marketable - US technologies. Officials are unreserved in their glee at entering what they see as a wide open market. "We intend to be as much larger than BTG-UK as the US economy is larger than the UK economy," is how Derek Schafer, director of the 16-person, £1-million US arm, put it at the launch of the US operation last September. "Expansion in the US is the key to BTG's future," says Ian Harvey, chief executive.

For the time being, BTG-USA plans to place top priority on finding US takers for technologies that are already in its portfolio. The second priority - searching for new technology in the United States - will be focused first on US industry, and then on universities.

BTG argues that it is offering something that university and industrial technology transfer offices generally can not: a wide reach and a fierce defence. Without any special allegiance to any one industry, BTG can take technology farther afield than the in-house technology transfer offices of most US companies. And unlike most US universities, BTG has long and painful experience in protecting licences once they have been obtained. A six-year battle with the US Defense Department ended last year with BTG winning a \$6.1 million out of court settlement over unauthorized use of the company's Hovercraft technology.

Offered a chance to avoid some of those pitfalls, some US technology managers are already joining the BTG expansion, although they harbour no illusions about penetrating the European market. "We can't do everything," says Jean Mahoney, manager of the Princeton University technology transfer office that has signed a deal with BTG. "We're a small office and we need the help. I'm not particularly going after the European market; I'm just trying to sell our stuff."

Mahoney says that US government grants (the largest source of research funding at Princeton) often come with the stipulation that any products that come from the government-funded research must be offered to US companies first. Mahoney can now satisfy the government by giving US companies first choice, while still retaining a realistic European option if domestic buyers opt out.

Once parliament completes the legislative process to privatize BTG (something that, barring a political surprise, is expected this autumn, thanks to heavy BTG lobbying), its US prospects are expected to look even better. US government researchers, who are at present forbidden to make deals with a foreign government (a class in which BTG now falls), will then be able to offer up their inventions as well. The National Institutes of Health and the national laboratories of the Department of Energy have both expressed interest in establishing links once BTG is privatized.

Perhaps the best indication of BTG's bright prospects as it enters the US market is the manoeuvring that has already begun among potential investors.
Both the Wellcome Trust and the Nuffield Foundation have expressed interest in buying part of BTG, as have several UK investment and pension funds. Even the 48 UK universities, who have often complained of being forced by the government to give BTG the right of first refusal on their inventions, are trying to raise money to buy into BTG when it goes private.

Christopher Anderson

\section{AIDS}

\section{Meeting to move}

Washington

The Harvard University organizers of the 8th International AIDS Conference planned for Boston in 1992 have decided to seek another location, outside the United States. At this year's conference in Florence, Max Essex of the Harvard AIDS Institute said the meeting would not be held in Boston unless the US government relaxed its controversial entry restrictions for people carrying the human immunodeficiency virus.

With no signs of movement on the issue from the US Administration, Essex says the time has now come to start making arrangements to hold the conference elsewhere. The conference now seems likely to take place in Europe.

Essex, who was to chair the 1992 meeting, has now handed over that responsibility to his Harvard colleague, Jonathan Mann, the former head of the World Health Organization's Global Programme on AIDS. "When I accepted the request to serve as chairman, .. I didn't anticipate that any of these political questions would be in the limelight," says Essex, who is remaining as co-chair of the meeting for the scientific sessions.

Peter Aldhous

\section{BRITISH SCIENCE}

We shall be publishing on 12 September Nature's Manifesto for British Science, which will be offered without charge to any one of the political parties contesting the next general election and in the belief that it is an improvement on their own version.

Following publication, on Friday 13 September, there will be a public meeting at the Royal Institution, Albemarle Street, London W1, at which Sir Mark Richmond, chairman of the Science and Engineering Research Council, will be the principal speaker. The chairman will be John Maddox, editor of Nature. The meeting will start at 9.45 a.m. and end at 12.45 p.m. The political parties will be invited to send representatives, but there will be ample time for discussion.

Those wishing to attend should apply for tickets to Mary Sheehan, Nature, 4 Little Essex Street, London WC2R 3LF. 